\title{
THE IMPACT OF MICRO-HYDRO POWER PLANTS IN INCREASING THE WELFARE OF RURAL RESIDENTS: A CASE STUDY OF BADAKHSHAN PROVINCE- AFGHANISTAN
}

\author{
Jamshid YOLCHİ 1 \\ Farzad AHMADİ 2
}

\section{ARTICLE INFO}

Article history:

Received 13 Feb 2021

Accepted 9 Nov 2021

\section{JEL classification: \\ R11 \\ Q01 \\ C21 \\ Q42 \\ 053}

\section{Keywords:}

Rural-development

Rural Electrification

Micro-Hydro power

Project Impact

Afghanistan

\section{MAKALE BILGIISI}

Makale Geçmişi:

Geliş Tarihi: 13 Şubat 2021

Kabul Tarihi: 9 Kasım 2021

\section{JEL kodu: \\ R11 \\ Q01 \\ C21 \\ Q42 \\ 053}

\section{Anahtar kelimeler:}

Kırsal Kalkınma

Kırsal Elektrifikasyon

Mikro-hidroelektrik

Santralleri

Proje Etkisi

Afganistan

\begin{abstract}
ÖZET
Afganistan, 2003 yılından başlayarak, Ulusal Dayanışma Programını (NSP) uluslararası toplumdan mali yardım alarak uygulamaya koydu ve tüm vatandaşlara temel hizmetler sunmaya odaklanmıştı. Programın büyük bir kısmı elektrifikasyon, kırsal yollar, içme suyu, okullar vb projelere harcandı. Badahşan ilinde, 443'ü mikro hidroelektrik santralleri olmak üzere NSP tarafindan 2713 proje uygulandı. Bu araştırmada 6 ilçeden 1070 örnek veri seti toplanmıştır. Veri analizi, projenin kırsal kesimde yaşayanların refahı üzerindeki etkisini bulmak için Eğilim Puanı Eşleștirme yöntemi ile yapılmıştır. Refahın tespiti için TV, bilgisayar ve telefon bulundurma vekil olarak kullanıldı. Sonuçlar, tedavi grubunun kontrol gruplarından daha fazla TV, bilgisayar ve telefona sahip olduğunu göstermektedir. Kesin olarak, tedavi grubu muadillerine göre \% 23,9 daha fazla TV, \% 7,6 daha fazla bilgisayar ve \% 37,6 daha fazla telefona sahiptir. Bu nedenle, Afganistan kendi sakinlerine elektrik sağlamak için mikro hidroelektrik santralleri inşa etmeye devam etmesi öneriliyor. Çünkü mikro hidroelektrik santralleri proje faydalanıcılarının refahına katkı sağlayıp artırmaktadır.
\end{abstract}

\footnotetext{
${ }_{1}^{1}$ Badakhshan University, Badakhshan, Afghanistan, jamshidyolchi@outlook.com, ORCID: 0000-0002-2710-8092

2 Badakhshan University, Badakhshan, Afghanistan, farzad.ahmadi133@gmail.com, ORCID: 0000-0001-7454-7808 DOI: $10.53839 /$ aifd. 875520
} 


\section{INTRODUCTION}

Since 2001, Afghanistan went through a tremendous change in delivering the basic public services to its citizens. Back then very basic needs of local people were unaddressed or the infrastructure of such services were devastated during the civil war of the 90s. Starting from late 2001, the new government initiated a series of programs in order to provide electricity, safe drinking water, road access and education services to local communities. One of very first and most successful programs was the National Solidarity Program (NSP) which led the charge towards the change by implementing 35000 projects and investing over $\$ 2$ billion over three phases of it. The mentioned program has helped the local communities especially in rural areas to construct their micro-hydro power plants, roads, drinking water systems and build schools. The program was under the scheme of $80 \%$ government funding and $20 \%$ contributions from the locals (Citizen Charter Program, 2019). This model has been largely used in other countries like India, Sri Lanka and Rwanda too (McCandless, 2007; Nanayakkara \& Nakamura, 2007).

With the NSP scheme Badakhshan province has received approximately $\$ 45$ million in funding from NSP for over 2713 projects with a contribution of roughly $\$ 7.5$ million from local communities. From all over this project the energy sector has accounted for $20 \%$ of them. 443 (346 of them micro-hydro power plants) energy projects have been constructed in this initiative in Badakhshan province with a total capacity of $5296.55 \mathrm{KW}$ of electricity (Program National Solidarity, 2019). Alongside the NSP other aid organizations are also constructed micro-hydro power plants (GIZ, 2019).

Despite all this investment in micro-hydro power plants in recent two decades in Afghanistan, there is lack of empirical research in order to find the impact of such initiatives in rural areas, especially the welfare effect of this program. In order to lead the way for impact evaluation, this research paper covers 6 districts of Badakhshan province in northeast Afghanistan. From all these 6 districts (namely Khash, Baharak, Argo, Yaftal, Darayim and Kishem) by questionnaire we have collected 1070 samples. As this research is a semi-experimental one, the data has been collected from two groups, the villages with micro-hydro power plants (the treatment group) and the ones without microhydro power plants (control group). From the total sample size 595 questionnaires were collected from the treatment group and 475 from the control group. The villages were selected based on their demographic and baseline characteristics from the NSP projects database, which has been reached from their provincial department in Badakhshan province. All the process of design, implementation, data collection and interpretation of the data has been carried out by the authors and a team of data collectors.

The proxy for welfare in this research is the ownership of TVs, computers and cellphones as well as hours of using the TVs and computers by the households. The data has been analyzed in STATA 16 using the propensity score matching technique. In the upcoming part the literature has been reviewed, data and methodology has been addressed, and the research ends with reporting the findings and conclusion.

\section{LITERATURE REVIEW}

In the literature the micro-hydro power plants are those with the capacity of under $1 \mathrm{MW}$ (Kaldellis, 2007). In this study the covered power plants capacities are not exceeding $280 \mathrm{KW}$, for this reason they can be classified under the micro-hydro power plants. 346 micro-hydro power plants which has been built in Badakhshan by NSP the total cost was $\$ 8.66$ million. Which is cost effective for $5296 \mathrm{KW}$ of electricity on average $1635 \$$ has been used to construct 1KW of electricity (Program National Solidarity, 2019).

For developing countries it's necessary to have electricity in distance areas and communities (liu, Masera, \& Esser, 2014), to foster the economic growth (Sadiqi et al. 2017) and they are cost effective and efficient than those of larger and small hydro-power plants. Because they don't need for heavy investment on electricity networks, maintenance and management (Kazimi et al. 1985). 
It's not just the developing countries taking the micro-hydro power plants approach to generate energy and also the developed countries are taking the same initiatives to deliver electricity services to remote and scattered populated areas. Because they are exhausting their main capacities on large and medium size dams and power plants so, they are heading towards the small and micro hydro-power plants, which are very efficient while serving the distant communities (liu et al. 2014; Kaldellis, 2007)

There are some studies concerning with usage, management schemes and the level of satisfaction as well as the outcome of the micro-hydro power plants in Afghanistan (Bhandari, Richter et al. 2015; Barakat, 2006; Beath et al. 2015). The rest of these studies were to find either the beneficiaries are satisfied with the level of outcome or not. The findings of this research indicates that the National Solidarity Program (among which the micro-hydro power plants were one the best initiatives of it) had a positive impact on the life of millions. This is because the residents have now access to water, electricity and participating in democratic processes.

The micro-hydro power plants in Afghanistan were built under the joint work between the government (NSP) and the local communities. With this scheme the government was trying to involve the local residents into finding the priorities for every area and engaging them to build and construct the projects which would have a significant impact on the level of success for the projects. This scheme has been done in several other countries which resulted in good outcomes for project management (Bajracharya et al. 2007; McCandless, 2007).

Unlike other micro-hydro power plants around the world, in Afghanistan's case the generated power is being used for light, TV, computer and cellphone charging. So in this case there won't be any concern regarding the impact of micro-hydro powers on economic growth, because the commercial and industry usages is nearly zero due to small scale capacity, which can cover only the needs of households. It's worth to mention that the majority of micro-hydro power plants has been built in villages that, there weren't any electricity services before. So, the capacities designed to meet the needs of households, not taking the economic activities into account in designing process. But in some countries the energy from the micro-hydro power plants has been used for industrial production and small scale businesses, resulting in the increase in production and income (Kirubi et al. 2009).

But the ownership remains to the community as in Afghanistan's case or some cooperatives have been involved in the process in some other developing countries (Khennas \& Barnett, 2000). The scheme of giving the ownership to the communities is that they are trying to minimize the opposition and transfer the responsibility of operating it to the community (Nanayakkara \& Nakamura, 2007). In every country as there are lots of micro-hydro powers operating them with a centralized entity would be challenging. As the communities can manage it very cost effectively and efficiently compared to those of centralized one (Ping, Jiang, \& Li, 2011; Yolchi, 2020).

The impact evaluation has been used to assess the effects of development projects on life of beneficiaries. So, governments for the purpose of policies effectiveness or policy changes, and academic institutions for academic use, are using the impact evaluation. Taking all these studies into account in the case of Afghanistan there is a gap in the area of impact evaluation of micro-hydro power plants. To fill this gap this study has been undertaken to uncover the level of magnitude of the impact of this initiative into the lives of local residents.

\section{DATA AND METHODOLOGY}

The data for this research paper have been collected from six districts of Badakhshan province which locates in North-eastern region of Afghanistan. The project has been designed by the authors and approved by faculty of economics of Badakhshan University. After completing the official procedure and ethical approval of the related department the project started. The data collection began in July 2019 and ended up at September 2019. All over 1150 questionnaires have been collected from 
which 1070 was complete and used in this paper. As micro-hydro power plants have not been constructed in every village with same projects, as the priorities and geographical realities varies, so there are villages with different projects in same district. Which is a unique chance for empirical researches to be conducted. Taking some characteristics like population of villages, language, and type of land as majority of the villagers with rain-feed or irrigated, as proxies to select them for both treatment and control groups. In this paper villages have been choose from selected districts to both treatment and control groups. Due to financial and manpower shortages, the sample size has been collected in certain number of villages in every district. In total 48 villages has been covered during the survey of this research project (25 for treatment and 24 for control group). Darayim district 4 villages, Khash district 5 villages, Baharak district 4 villages, yaftal district 6 villages, and Kishem district's 6 villages in treatment group; while in control group Darayim district 4 villages, Khash district 5 villages, Baharak district 4 villages, Kishem district 5 villages, and Argo district 5 villages ( as control group of Yaftal district).

The capacity of the micro-hydro power plants which have been covered in this research vary from $5 \mathrm{kWs}$ to $250 \mathrm{kWs}$. The photos of such micro-hydro powers added in appendix 2. After starting the analysis and data cleaning 595 of the sample size from the treatment group was complete and 475 of the control group.

As this research is using a semi-experimental approach to analyze the impact of project in the welfare of local residents of Badakhshan province, the only method which could be used was the Propensity Score Matching Technic. In order to guarantee the accuracy the results were cross checked with other methods such as Nearest Neighbor Matching and Regression Adjustment. The notion of Matching Technique can be explained as follow:

$$
A T T=E\left(Y_{1} \mid P=1\right)-E\left(Y_{0} \mid P=0\right)
$$

Which ATT stands for Average Treatment effect on Treated, $\mathrm{Y}$ is the outcome and $\mathrm{P}$ is the project (in here the micro-hydro power), $\mathrm{E}\left(\mathrm{Y}_{-} 1 \mid \mathrm{P}=1\right)$ stands for mean of treated group and $E\left(Y_{-} 0 \backslash \mid P=0\right)$ stands for mean of control group in a given time as the data has been collected in cross sectional manner. But in this research the following model has been used, because there is no baseline data.

Here the assumption is that the treatment and control groups are the same in baseline characteristics and the only variable which caused the difference between them is the project itself. If there were no projects of such kind the two groups of people would have been the same in interest dependent variables. But if they are different now, by keeping in mind that they are assumed the same in baseline characteristics the source of that change will be the project intervention which has been made in the treatment group (Gujarati, 2004; White \& Raitzer, 2017). Among Propensity Score Matching methods, Nearest Neighbor Matching has been selected in this paper because it has used frequently in research papers. In Nearest Neighbor Matching each units of treatment group will be matched with one of comparison group based on nearest propensity score, the process can be applied with or without replacement. For instance in with replacement a comparison group member will be used for several times against different treatment group member (Khandker et al. 2010). The balancing property of Propensity Score Matching has been reported in Appendix 1. Also, by logit model the results of matching method has been tested for more precision and accuracy.

\section{EMPRICAL FINDINGS}

In the empirical findings part, descriptive statistic has been added to give clearer picture on the data which used in the analysis. Then the findings based on Nearest Neighbor Matching Technic of propensity score matching has been report. In order to check the reliability of the matching process, propensity score matching between treatment and control group has been reported in Appendix 1. 
Table 1: The Sources of Lighting before Micro-hydro Power Projects

\begin{tabular}{c|ccc}
\hline Sources of Lighting before the project & Frequency & Percentage & Cumulative \% \\
\hline Torches & 1 & $0.20 \%$ & 0.20 \\
Battery powered Torches & 21 & $4.19 \%$ & 4.39 \\
Natural gas & 4 & $0.80 \%$ & 5.19 \\
Solar Panels & 181 & $36.13 \%$ & 41.32 \\
Diesel Torches & 294 & $58.68 \%$ & 100.00 \\
\hline Total & 501 & $100.00 \%$ & \\
\hline
\end{tabular}

As it's obvious from Table 1 before the implementation of the micro-hydro power plants projects, a big proportion (approximately 59\%) of the residents of the treatment group were using diesel torches (a kind or torch burning diesel and generating light). Second place is the solar panels (using solar panels electricity generation for lighting and other home appliances), which are good for being clean, but are expensive. Also some families mentioned that they are using natural gas powered torches for lighting sources of their houses. Right after the project implementation in the area the lighting sources are now 100\% electricity.

Table 2: Descriptive Statistics of Dependent Variables

\begin{tabular}{|c|c|c|c|c|}
\hline \multirow{2}{*}{ Dependent Variables } & \multicolumn{2}{|c|}{ Treatment Group } & \multicolumn{2}{|c|}{ Control Group } \\
\hline & Mean & $\mathrm{Sd}$ & Mean & sd \\
\hline Hours of Watching TV & 3.14790 & 3.35774 & 1.34105 & 1.92953 \\
\hline Hours of Using Computer & 0.55714 & 1.37103 & 0.26737 & 0.86303 \\
\hline Number of cell phones & 2.68739 & 2.41134 & 2.32000 & 1.57470 \\
\hline $\mathrm{N}$ & \multicolumn{2}{|c|}{595} & \multicolumn{2}{|c|}{475} \\
\hline
\end{tabular}

Note: sd- standard deviation

Looking at Table 2 there is a comparison between treatment and control groups of dependent variables. It's obvious the means of treatment group are bigger than those of the control group, which is a clear sign of differences between households of two groups. For instance the means of having TV in the treatment group is 3.1479 while in the control group that's 1.3411 .

Table 3: Distribution of TV, Cellphones and Computers' Possession in Control and Treatment Groups

\begin{tabular}{l|llll}
\hline Households & Treatment Group & Control Group & Total & $\%$ \\
\hline With TV & 362 & 175 & 537 & 50.19 \\
Without TV & 233 & 300 & 533 & 49.81 \\
\hline Total & 595 & 475 & 1070 & 100 \\
\hline With cellphone & 576 & 461 & 1037 & 96.92
\end{tabular}




\begin{tabular}{l|llll} 
Without cellphone & 19 & 14 & 33 & 3.08 \\
\hline Total & 595 & 475 & 1070 & 100 \\
\hline With Computer & 112 & 53 & 165 & 84.58 \\
Without Computer & 483 & 422 & 905 & 15.42 \\
\hline Total & 595 & 475 & 1070 & 100 \\
\hline
\end{tabular}

As it's clearly indicated in Table 3, the distribution of assets which have been taken as proxy. There are differences in possession of computers and TV among treatment and control groups while there is less difference between them in cellphone possession.

Table 4: Results of Nearest Neighbor Matching Method from Impact of Micro-hydro Power Plants

\begin{tabular}{c|ccc}
\hline Dependent Variables & ATT & SE & T-value \\
\hline TV possession & $\mathbf{0 . 2 3 9}$ & 0.030 & 8.013 \\
Computer Possession & $\mathbf{0 . 0 7 6}$ & 0.022 & 3.531 \\
Cellphone Possession & $\mathbf{0 . 3 6 6}$ & 0.122 & 2.987 \\
\hline
\end{tabular}

Treatment group: 595 control group: 475 ATT- Average Treatment on Treated SE- Standard Error

The results from Nearest Neighbor Matching which is reported in Table 4 under ATT (Average Treatment Effect on Treated), indicates that the micro-hydro power plants had statistically significant impact on assets that this paper took as a proxy for welfare. The project has increased the possession of TV in treatment group by $23.9 \%$ which is statistically significant in $99 \%$ confidence level. Which is a good improvement in lifestyle and quality of life for villagers. The computer possession has increased by $7.6 \%$ which is also statistically significant in $99 \%$ confidence level. It's much smaller impact compared to TV possession, but taking this into consideration that the majority of villagers are illiterate this increase is also a positive and good change in life of those affected by the project. The last one is the cellphone possession which the treatment group has $36.6 \%$ more than those of the control group with 99\% statistically significance level. The mentioned results have been tested with other matching methods for more accuracy. Also, a logit model run for all three interest variables, the results were not much different despite controlling for geographical difference and income. Just the education showed a relationship with computer ownership, which is quit as expected. It's worth mentioning that the questions for TV and computers were asked as they have or haven't but as nearly $95 \%$ of the households had somehow cellphones. So the question was asked how many cellphones you have.

\section{CONCLUSION}

Afghanistan as a developing country has tried to overcome the obstacles in delivering the basic needs for its citizens in the past 20 years. In this regard the international community has helped the country by funding the initiatives taken by NGOs or the Afghanistan Government. One of the biggest of its kind is the National Solidarity program (NSP), which has covered all over districts of Afghanistan with 35000 projects and over $\$ 2$ billion in budget. The NSP program funded district councils and gave them the freedom to select their own project based on their priorities and local needs. The councils 
implemented the projects and took part in expenditures by $\% 20$ share. Local roads, schools, micro-hydro power, community centers and handicraft centers have been implemented. This research paper has covered the micro-hydro power plants impact evaluation in Badakhshan province.

By using the nearest neighbor matching method and 1070 samples from 6 districts of Badakhshan province which 595 of them were treatment group and 475 of them from control group. The mentioned method assumes that both treatment and control groups are the same in baseline characteristics and if the project wasn't implemented both of them would be changing in the same manner. But if there is any significant change between these two groups after implementation of the project the impact is assumed to be caused by the project (micro-hydro power).

The findings indicate that before the project, the majority of local residents were using diesel torches (59\% of them) which shows that in 21st century we are using the methods of lighting of 19th centuries. It is a huge drawback for every country, in the modernized today world.. As using diesel torches will have health problems and not as good as electricity is, in brightness and availability.

This research paper takes the possession of TV, computers and cellphones as a proxy for project impact on welfare of local residents. The empirical findings show that the mean of the treatment group in all three interested variables are statistically significant than those of the comparison group. The results show that the treatment group has \%23.9 more TV compared to the comparison group, which is statistically significant in \%99 confidence level. Also \%7.6 more computers and \%36.6 more cellphones than comparison group. It's easy to conclude that this impacts are from the microhydro power plants projects, because controls of income, education level and district has been added. So, the only impacting variable between control and treatment groups are the project of hydro-power. Taking all these findings into consideration, the final conclusion would be that micro-hydro power projects had a statistically significant impact on welfare of local residents.

\section{ACKNOWLEDGEMENT}

The authors want to extend their gratitude to Mr. Mohammad Naim Maleki for reading and commenting of an early version of this paper. 


\section{BIBLIOGRAPHY}

Bajracharya, S. B., Gurung, G. B., \& Basnet, K. (2007). Learning from Community Participation in Conservation Area Management. Journal of Forest and Livelihood, 6(2).

Barakat, S. (2006). Mid-term Evaluation Report of the National Solidarity Program (NSP), Afghanistan. York: The University of York.

Beath, A., Christia, F., \& Enikolopov, R. (2015). The National Solidarity Programme: Assessing the Effects of Community-Driven Development in Afghanistan. International Peacekeeping, 22(4), 302-320. doi:10.1080/13533312.2015.1059287

Bhandari, R., Richter, A., Möller, A., \& Oswianoski, R.-P. (2015). Electrification using Decentralized Micro Hydropower Plants in North-eastern Afghanistan. Journal of Sustainable Development of Energy, Water and Environment Systems, 3(3), 4965.

doi:http://dx.doi.org/10.13044/j.sdewes.2015.03. 0004

Citizen Charter Program. (2019). www.ccnpp.org. Retrieved $11 \quad 22, \quad 2019$, from http://www.ccnpp.org/PageDari.aspx?PageID=15

GIZ. (2019, 10 30). Deutsche Gesellschaft für Internationale Zusammenarbeit (GIZ). Retrieved from GIZ Web Site: https://www.ezafghanistan.de/prs/story/\%d8\%af\%d8\%b3\%d8 \%aa\%da\%af\%d8\%a7\%d9\%87-

\%da\%a9\%d9\%88\%da\%86\%da\%a9-

\%d8\%aa\%d9\%88\%d9\%84\%db\%8c\%d8\%af\%d8\%a8\%d8\%b1\%d9\%82-

\%d8\%a2\%d8\%a8\%db\%8c-\%e2\%80\%93-

\%d8\%a8\%db\%8c\%d8\%b4-\%d8\%a7\%d8\%b2\%d8\%a7\%d9\%86\%d8\%b1\%da\%98\%db\%8c

Gujarati, D. (2004). Basic Econometrics. London: McGraw-Hill Companies.

Kaldellis, J. (2007). The Contribution of Small Hydro-Power Stations to the Electricity Generation in Gereece: Technical and Economic Considerations. Energy Policy, 35, 2187-2196.

Kazimi, S. H., Rukni, A., \& Bathani, S. M. (1985). Economical Assessment of Producing Energy in
Micro-hydro Plants. Isfahan Regional Electric Company , 1-12.

Khandker, S. R., Koolwal, G. B., \& Samad, H. A. (2010). Handbook on Impact Evaluation Quantitative Methods and Practices. Washington D,C: The International Bank for Reconstruction and Development / The World Bank. doi:10.1596/9780-8213-8028-4

Khennas, S., \& Barnett, A. (2000). Best Practices for Sustainable Development of Micro Hydro Power in Developing Coutries. Washington D.C: World Bank.

Kirubi, C., Jacobson, A., Kammen, M., \& Mills, A. (2009). Community-Based Electric Micro-Grids Can Contribute to Rural Development: Evidence from Kenya. World Development, 37(7), 12081221.

liu, H., Masera, D., \& Esser, L. (2014). World Small Hydropower Development Report 2013. United Nation Industrial Development Organization, Internal Center on Small Hydro Power. Retrieved from www.smallhydropower.org

McCandless, M. (2007). Community Involvement in the Development of Small Hydro in Uttaranchal, India. Winnipeg, Manitoba: University of Manitoba.

Nanayakkara, N., \& Nakamura, M. (2007). Best Practice Implementation Strategies of Community Based Village Hydro Power Projects for Sustainable Operation. IEEE, 272-276.

Ping, Z., Jiang, Z., \& Li, C. (2011). Satatus and Future Perspective of Energy Consumption and Its Ecological Impacts in the Qinghai-Tibet Region. Renewable and Sustainbel Energy Reviews, 15, 514-523.

Program National Solidarity. $(2019,6)$. Projects Consturacted Under the National Solidarity Program in Badakhshan. Faizabad, Badakhshan, Afghanistan: Department of Rural Rehabilitations and Development.

Sadiqi, S. K., Sijudi, S., \& Deljawan, F. A. (2017). The impact of Renewable Energies in Economic growth and Evironment quality in Iran. Quarterly Jounal of Research in Energy Policy Making and Planning, 132. 
White, H., \& Raitzer, D. A. (2017). Impact Evaluation of Development Interventions $\mathrm{A}$ Practical Guide. Manila: Asian Development Bank.
Yolchi, J. (2020). Management Schemes of Local Community Consels of Micro-hydro Power Plants: A case Study of Badakhshan Province. Faizabad: Badakhshan University. 


\section{Appendix 1:}

Figure 1: Propensity Score of the Dataset Used in the Research

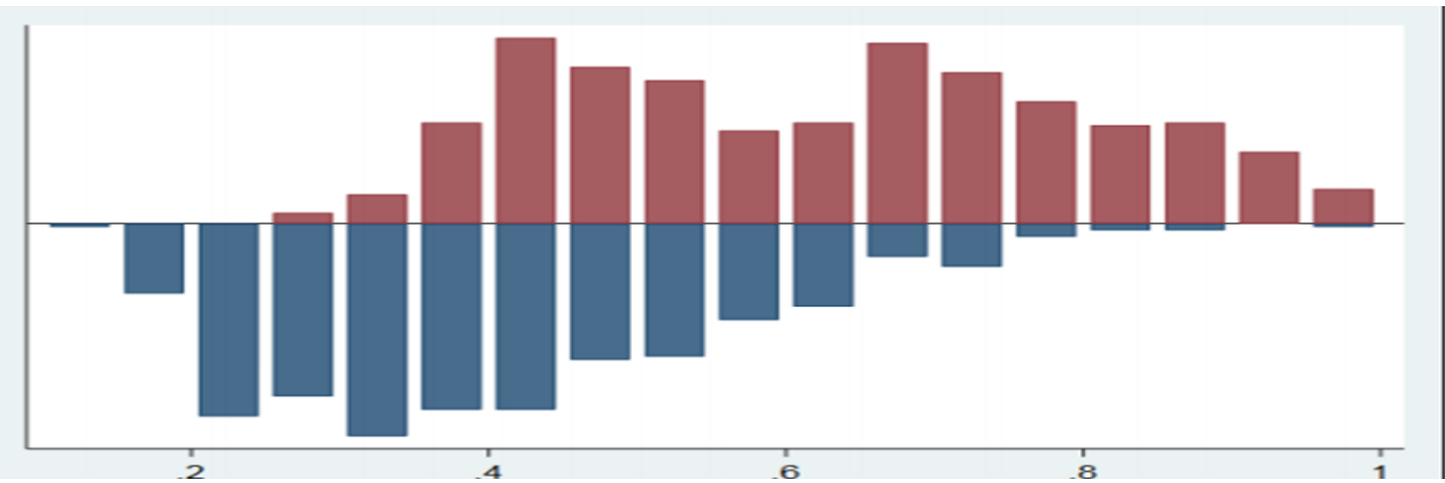

Propensity score

\begin{tabular}{|c|c|c|c|}
\hline Treatment group & & Control group & \\
\hline
\end{tabular}

\section{Appendix 2:}

Picture 1: A view of Micro-hydro Power Plant- Badakhshan Province-Afghanistan

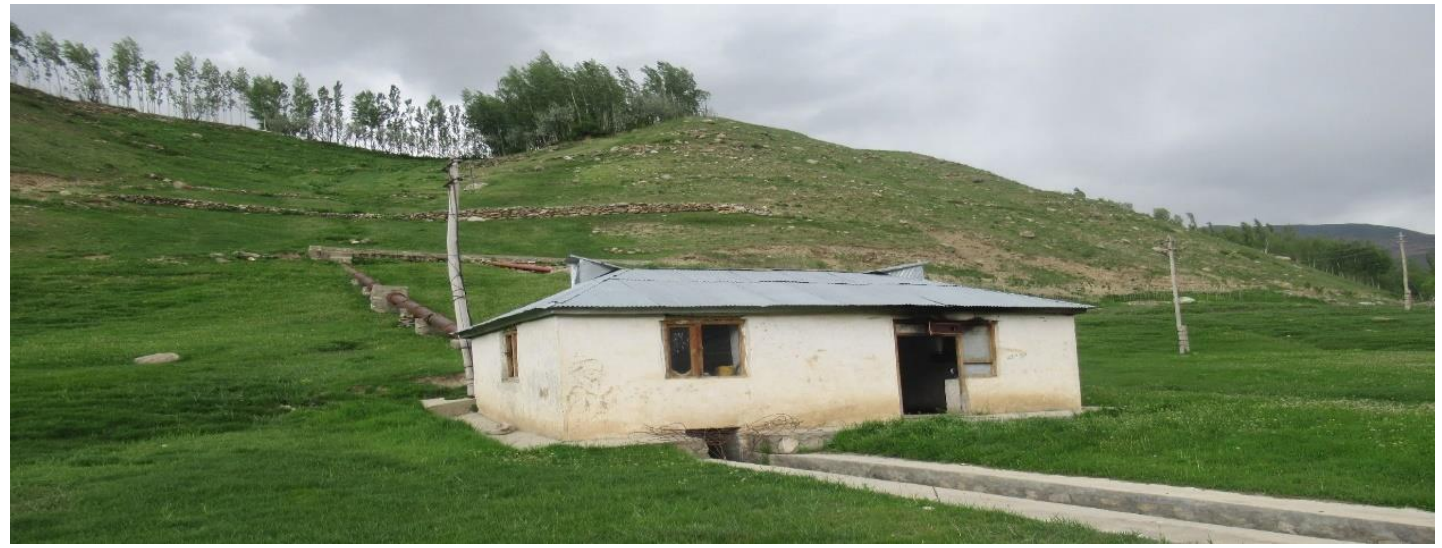

Picture 2: Turbine of one of Micro-hydro Power Plants- Badakhshan Province-Afghanistan

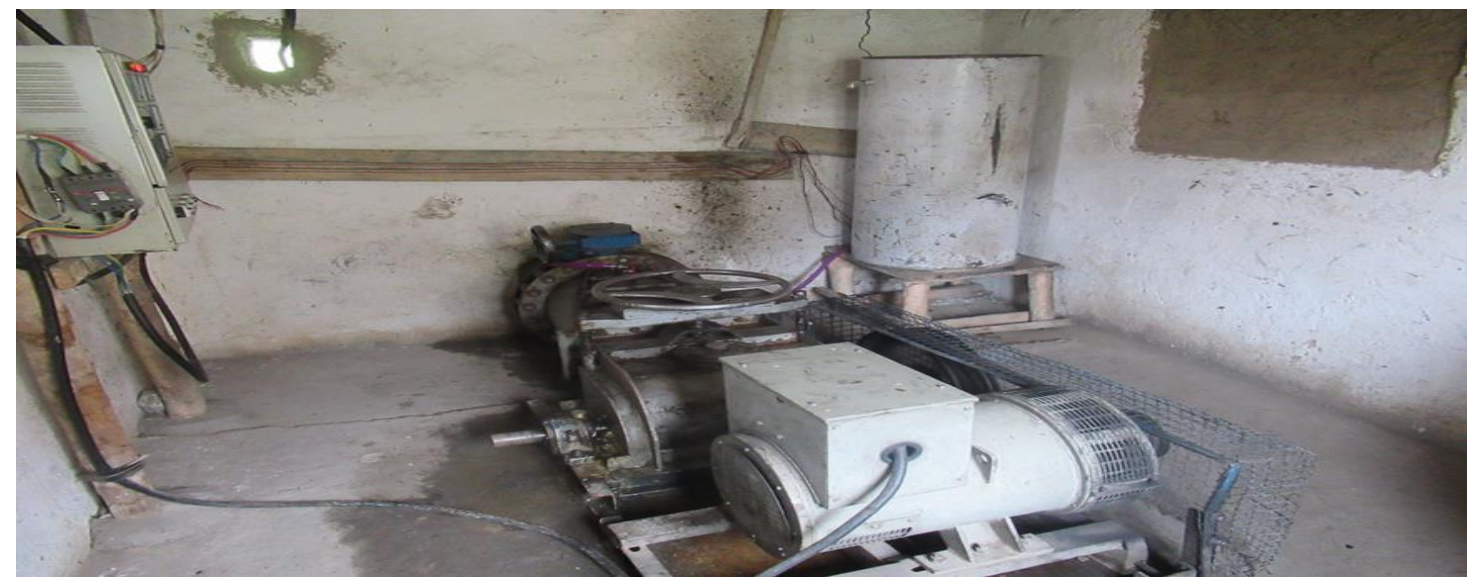

